\title{
Urban water consumption in water-stressed areas of the developed world: an examination of multiple interrelated variables
}

\author{
Alvaro-Francisco Morote* and \\ María Hernández \\ Interuniversity Institute of Geography, \\ University of Alicante, \\ Carretera de Sant Vicent del Raspeig, \\ s/n - Apartado 99, (03080), Alicante, Spain \\ Email: alvaro.morote@ua.es \\ Email: maria.hernandez@ua.es \\ *Corresponding author
}

\section{Saeid Eslamian}

Department of Water Engineering, Isfahan University of Technology, HezarJerib st., 81746, Isfahán, Iran Email: prof.s.eslamian@gmail.com

\begin{abstract}
The developed world has witnessed significant land changes since the second half of the 20th century. These include a process of intensive urban development, which is also accompanied by the growth in the urban population and housing. One of the outcomes of this process has been an increase in the consumption of resources, including water. The aim of this paper is to identify and analyse the factors affecting water consumption and the areas studied in water-stressed regions of the developed world. A literature review of territorial studies examining the factors that affect urban water consumption in these areas was conducted methodologically. The results reveal that: a) a significant number of papers have been written on water consumption factors in areas where there is substantial urban growth; and b) North America and Australia, have been compared to the rest of the developed world (especially Southern Europe), recently (since 2000s) due to the expansion of the low-density urbanism in the last few years.
\end{abstract}

Keywords: water; urban; factors; consumption; water-stressed areas; developed world.

Reference to this paper should be made as follows: Morote, A-F., Hernández, M. and Eslamian, S. (xxxx) 'Urban water consumption in water-stressed areas of the developed world: an examination of multiple interrelated variables', Int. J. Hydrology Science and Technology, Vol. X, No. Y, pp.xxx-Xxx.

Biographical notes: Alvaro-Francisco Morote is a Researcher in the Interuniversity Institute of Geography at the University of Alicante, Spain. His research interests include studies about water consumption, the urbanisation process, and the study about the relation about new urban natures (gardens and pools) with water demand and natural hazards. 
María Hernández is a Full Professor of Geography in the Interuniversity Institute of Geography at the University of Alicante, Spain. Her research interests, initiated in 1994, are focused on studies on analysis and evolution of rural and cultural landscapes, agriculture and rural development, tourism and local development, land management, demand and water uses, and natural hazards.

Saeid Eslamian is a Full Professor of Water System Engineering in the Department of Water Engineering at Isfahan University of Technology, Iran, where he was been since 1995 . His research focuses mainly on water resources planning, management and sustainability, and statistical and environment hydrological in a changing climate.

\section{Introduction}

There have been significant territorial changes in the developed world since the second half of the twentieth century (Nazari et al., 2013). These include a process of intensive urban development, accompanied by a considerable increase in the urban population and housing (Membrado, 2015). In 2000, the United Nations Development Programme estimated that $55 \%$ of the world's population would be city dwellers by the year 2015 , but more than half of the world population live in urban areas in 2017. These changes have been most obvious in the USA (Fernández and Barrado, 2011; House-Peters and Chang, 2011; Chen et al., 2015), Australia (Troy and sHolloway, 2004; Hurd, 2006) and the developed Mediterranean countries such as Italy (Salvati and Sabbi, 2011), France or Spain (Burriel, 2009; Morote and Hernández, 2016a).

It is estimated that by 2050 , water consumption will have increased by $44 \%$ in order to meet the demands of industry and the population (Fundación Aquae, 2015). However, there is considerable empirical evidence that suggests that the demand for water has dropped in recent decades in most of the large urban agglomerations in developed countries (Deoreo and Mayer, 2012; Gil et al., 2015; Morote et al., 2016a).

It is therefore necessary to gain more insight into the factors affecting domestic water consumption and their interrelationships. Studies on water conservation and especially those on urban water conservation in the developed world (Inman and Jeffrey, 2006) have mostly focused on certain areas of North America (House-Peters and Chang, 2011) and Australia (Llausàs and Saurí, 2016). These studies assume that low-density urbanism and high outdoor water uses are prevalent realities of these cities. By examining other environmental settings, a wider variety of factors influencing water conservation practices can be assessed more comprehensively. Most notably, the important influence of different community models of water consumption and the potential of urban and regional planning for water conservation have to be put at the forefront of research and practices on this topic (Saurí, 2013). This is of vital importance in terms of planning future water demand scenarios, taking into account continued urban population growth, episodes of water stress, drought events and the impact of the climate change on the availability of water resources, among other issues (Intergovernmental Panel on Climate Change, 2014; Chang et al., 2014). Various aspects of the factors affecting levels of demand for water resources have become priority research topics in recent decades, especially in water-stressed areas that have experienced particularly intensive urban 
development processes (Hernández et al., 2014). The relationships between these factors must be analysed along with the changes in them in recent decades.

As factors affecting levels of demand for water resources have become priority present-day research topics, the hypothesis of this research work is to determine whether those factors in space are related (that it is to say, if there are differences between Anglo-Saxon areas and Mediterranean Europe) in time, and why, focusing on evidence that suggests that the demand for water has dropped in the last few decades in the majority of the large urban agglomerations in developed countries. The factors that are considered are: social-demographic, household characteristics and the urban model, political-economic, psychological and climatic factors. These factors are chosen because they are associated with the categories identified by the scientific literature that analyses relationships between urbanisation and water consumption.

The general aim of this research work is to identify territorial studies exploring the factors that influence urban water consumption in the developed world and particularly in water-stressed areas where substantial urban development has been recorded. Developed countries are identified according to the International Monetary Fund (see http://www.imf.org/external/country/index.htm), that defines them as being 'advanced economies'. Although it analyses territorial papers related to water consumption factors in water-stressed areas of the developed world, urbanisation has been growing faster in some parts of the underdeveloped world (Africa or Asia) than in the developed world. This area of study is justified by the factors that explain why urbanisation processes are different in the developed and the underdeveloped world. Firstly it is related to the diffusion of urban sprawl and outdoor uses. Secondly there is an intense process of migration from the countryside to urban areas due to the structural crisis affecting the latter and the proliferation of unplanned informal urban settlements. These diverse processes determine different incidences in water consumption related to uneven distribution and access to clean drinking water, a distorted distribution network and sewage system, etc. in African, Asian or Latin American cities.

These different processes determine different incidences in water consumption. Moreover, 'water-stressed areas' such the regions where the demand for water is higher than the water resources available were identified and not only with regard to arid or semi-arid areas. A physical factor associated with the lack of rainfall through aridity must be understood. In view of this more physical concept (aridity), the water shortage term or that of water-stressed areas incorporated elements associated with the use of the water (anthropic factor). The shortage represents a deficit situation in relation to water demands in a resource system, which is characterised by an arid climate or by a fast growing water demand. The water shortage is a situation in which the water available is not enough to meet the demand. The specific objectives of this paper focus on identifying these potential differences and what factors actually produce them. These issues could be the new main contribution to this research work, especially the change in the water consumption trend over the last few years.

The paper is structured as follows. A brief introduction explaining the increase in the demand for urban water consumption in the developed world, the interest of this research work in water-stressed areas and the objectives, followed by a description of the methodology. Then, the results of a review of the literature on the various factors that influence water consumption are presented with particular attention being paid to the differences between land areas subjected to water stress and the factors that explain the 
drop in consumption. These results are organised according to three key elements: the different lines of research, the authors and the study areas. This is followed by discussions and the conclusions of the results drawn from this study.

\section{Methodology}

The research methodology consisted in a literature review (since the 1980s) of the territorial studies that examine the factors affecting urban water consumption in the developed world and particularly in water-stressed areas. To this end, a literature search was organised using databases such as 'Scimago' and the 'Web of Science Core Collection'. The search terms selected were keywords related to the factors that influence water consumption, namely water, consumption, factors, urban development, demand, water supply, water footprint, tourism, gardens and swimming pools, water-stressed areas, Australia, USA and Mediterranean Europe. A filter was applied to the results obtained in this first phase (1,843 studies) to eliminate references that concerned water, but did not focus on an analysis of the factors influencing consumption. Consequently, studies that examined issues related to water quality or the consumption for agricultural purposes were excluded.

Secondly, the 'State of the art' publications written previously on factors affecting urban water consumption in the developed world were also identified (Hurlimann et al., 2009; House-Peters and Chang, 2011; Saurí, 2013; Llausàs and Saurí, 2016). This helped show how these factors and their interrelationships have been treated by the scientific community in former papers and also how to focus on our specific objectives (show differences between water-stressed areas). Thus, the aim of this research work is not to compile the largest possible number of studies on the subject matter of water demand and consumption, but rather to select the most representative work on factors affecting consumption that have had an impact on the subsequent research and to highlight the differences between different territorial areas and the factors that explain the changing trends in water consumption. The purpose (territorial effects on water demands) was one of the lenses used to filter references. Having identified these references, another lens was applied: innovation in theory and arguments in line with prevailing ideas when the factor analysed has been perceived by the scientific community as being predominant.

Finally, a total of 111 studies were analysed (including articles, books and book chapters). With the items obtained, they were then classified according to the factors analysed and locations studied. In a second phase, several features associated with these factors were identified and particular attention was paid to possible differences pinpointed by analysing these factors according to territorial areas. Thirdly, an attempt was made to identify:

a the causes behind that different treatment

b the relationships between lines of research

c possible physical, ecological and socioeconomic characteristics that explain the interest in each factor.

Fourthly, the changes in the factors identified and their relationships with the empirical evidence suggest that the demand for water has dropped in recent decades in the majority of the large urban agglomerations in developed countries. 
Once the information had been extracted, the results of the literature search about the main factors affecting urban water consumption were grouped together in five thematic areas:

1 social-demographic analysis

2 housing characteristics and the urban model

3 political-economic

4 psychological

5 climatic factors

Nonetheless, as a result of the subjects analysed, some studies and authors highlighted an overlap between thematic groups. In such cases, these were included in all relevant groups. Furthermore, not all the studies identified are examined in depth here seeing as this would have prolonged the research work considerably, as well as going outside the scope of this article.

\section{Results}

To present the results of this territorial literature review on the factors that influence urban water consumption, the information obtained has been divided into different thematic groups related to the factors that influence urban water consumption in the developed world and particularly in water-stressed areas (social-demographic factors, housing characteristics and urban models, political-economic factors, psychological and climatic factors) and specific features that explain the drop in consumption. These factors will be simply analysed consecutively, even though interrelationships between some of them are obvious.

\subsection{Water consumption and social-demographic factors}

The impact of socio-demographic factors on water consumption has been the subject of extensive research in many areas of the world for a long time. The studies reviewed here focused on how the number of people per household, age and the origin of residents have had an influence. The main study areas were in the USA, more specifically in the states of Arizona (Tucson and Phoenix) and Texas (San Antonio), and Australia (cities of Adelaide and Sydney). The reason why these areas are prominent is that there has been significant population growth associated with economic dynamics, and because their urban population is very high in relation to the total state population. In turn, an analysis of this factor pinpointed a pronounced relationship with the climate and urban model, with a predominance of low-density urbanism (Figure 1).

Studies that established a link between water consumption and the number of people per household, for example the study carried out in the USA by Mitchell (2001), found that a decline in the number of household residents has not resulted in decreased water consumption. However, consumption has increased due to the rising number of single occupancy homes. The effect of this process is that some water uses, such as water for washing kitchenware or clothes, or for external elements of the house (gardens and 
swimming pools), are no longer shared as they were formerly. For example, in homes occupied by families with 3 or more members as it was shown in Madrid, Spain (Cubillo et al., 2008).

Figure 1 Evolution of number of studies about water consumption factors

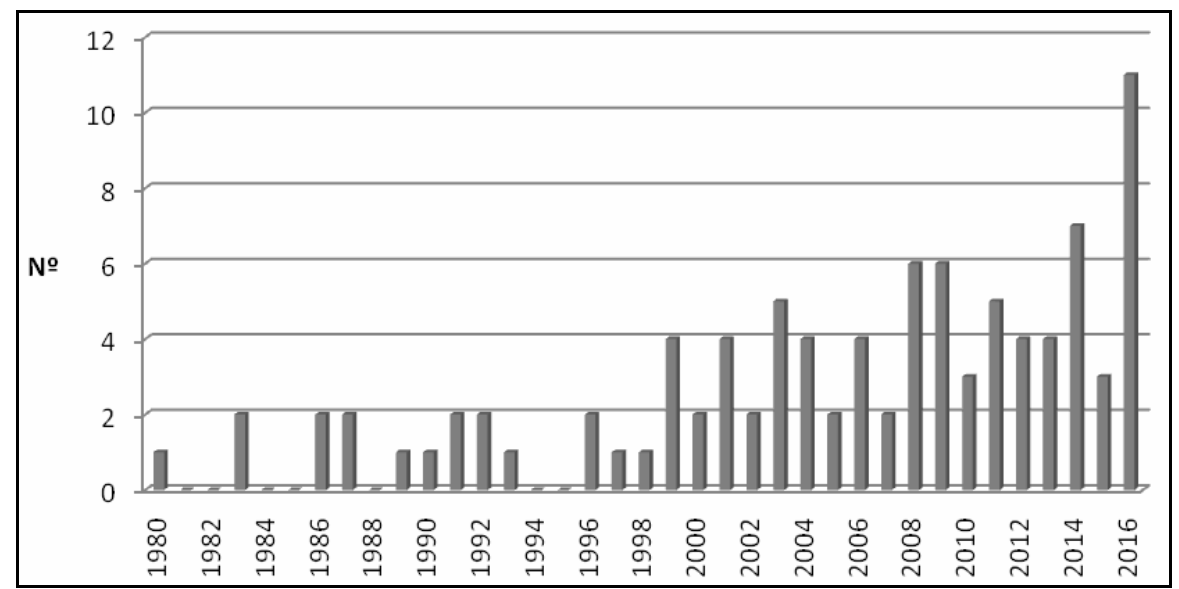

Source: Authors

A second socio-demographic factor associated with water consumption is the age of the residents. Nauges and Thomas (2000) and Troy et al., (2005) conducted studies in France and Australia, respectively, and found that average water consumption was higher in young people's homes than in pensioners' households. They attributed this to a higher frequency of daily personal hygiene (showers) and the increased consumption of water for external, recreational uses, usually associated with the presence of children. In the case of Spain, Albiol and Agulló (2014) and Morote et al., (2016b) observed that one of the reasons behind the reduction in domestic water consumption along the Mediterranean coast was the presence of an ageing population and the loss of younger population cohorts due to migration prompted by the economic crisis that erupted in 2007. They reported that a person aged 65 or more consumes $25 \%$ less water than the previous population segment (18 to 64 years). Numerous studies have reported the same findings (less water consumption in houses where seniors live), such as those conducted by Gregory and Di Leo (2003) in Shoalhaven (New South Wales, Australia).

The third factor analysed is the relationship between domestic water consumption and the origin of residents. As with the previous variable, an analysis of the literature revealed a diversity of opinions due to the numerous factors that influence these criteria, including the type of emigration (i.e., economic or the so-called climate residents), the level of education, and water-related activities associated with cultural or religious practices. In their studies of the state on Texas (USA), Griffin and Chang (1990) and Gaudin et al., (2001) observed that water consumption is higher in households with Latin American residents because these homes have a higher number of occupants with a low level of studies and income and little environmental awareness. In contrast, Nauges and Reynaud (2001) conducted a study in the Departments of the Moselle and the Gironde (France) and concluded that immigrants from developing countries were characterised by more austere water consumption. March et al. (2012) showed similar results in the study 
conducted in Barcelona (Spain) where water consumption is lower in neighbourhoods where economic immigrants live. Nevertheless, this behaviour and trend could change. A study conducted in the city of San Antonio (Texas, USA), De Oliver (1999) found that after a series of environmental awareness campaigns, the results obtained in terms of the acceptance and adoption of water saving measures differed from one ethnic group to another.

Table 1 Studies about water consumption and social-demographic factors

\begin{tabular}{lccc}
\hline Year & Country & Variables & Authors \\
\hline 1990 & USA & Origin of residents & Griffin and Chang \\
1992 & USA & Age of residents & Lyman \\
2000 & France & Age of residents & Nauges and Thomas \\
2001 & USA & Origin of residents & Gaudin et al. \\
2001 & USA & Number of people per household & Mitchell \\
2001 & France & Origin of residents & Nauges and Reynaud \\
2003 & Australia & Age of residents & Gregory and Di Leo \\
2005 & Australia & Age of residents & Troy et al. \\
2006 & Australia & Urban model & Hurd \\
2007 & USA & Origin of residents & Wentz and Gober \\
2010 & USA & Urban model & Chang et al. \\
2012 & Spain & Level of household income & March et al. \\
2014 & Spain & Age of residents & Albiol and Agulló \\
2014 & Spain & Origin of residents & Morote and Hernández \\
2015 & Spain & Place attachment of the residents & Age of residents \\
$2016 b$ & Spain & Age of residents & Gil et al. \\
& & Level of household income & Morote et al. \\
& & Number of people per household & \\
\hline
\end{tabular}

Source: Authors

\subsection{Water consumption, household characteristics and the urban model}

The relationship between water consumption and urban development has been studied from many perspectives (e.g., geography, urban planning and economics) and numerous factors have also been analysed. Some studies have associated consumption with housing characteristics (e.g., age, number of rooms or bathrooms and plot size) whereas others have examined the influence of urban typologies and external elements of the houses (gardens and swimming pools) (Morote et al., 2016a).

The former analysed housing characteristics such as plot size, the location of the property in relation to the various districts consisting of a city or ownership (owner-occupied or rented). Numerous studies have reported that water consumption increases the bigger the housing plot size (Plint, 1999; Troy and Holloway, 2004) in owner-occupied property (Gardener and Stern, 1996) and in housing located in medium and high income areas (Troy and Holloway, 2004). Troy and Holloway (2004) analysed water consumption patterns for different types of housing in the city of Adelaide 
(Australia) and found that this variation was related to different types of residential housing (single-family homes, terraced houses, apartments, etc.). They concluded that acquiring knowledge of these consumption patterns at a local level would enable planners and public administrators to promote the adoption of environmental policies and specific initiatives aimed at reducing water consumption.

Table 2 Studies about water consumption, household characteristics and urban model

\begin{tabular}{|c|c|c|c|}
\hline Year & Country & Variables & Authors \\
\hline 1980 & USA & Housing characteristics & Syme et al. \\
\hline 1986 & USA & Housing characteristics & $\begin{array}{l}\text { Chicoine and } \\
\text { Ramamurthy }\end{array}$ \\
\hline 1989 & USA & Housing characteristics & $\begin{array}{l}\text { Nieswiadomy and } \\
\text { Molina }\end{array}$ \\
\hline 1990-1991 & Australia & Gardens and pools & Syme et al., \\
\hline 1996 & USA & Housing characteristics & Gardener and Stern \\
\hline 1996 & Australia & Housing characteristics & Barkatullah \\
\hline 1997 & Australia & Housing characteristics & Dandy et al. \\
\hline 1998 & Australia & Gardens and pools & Renwick and Archibald \\
\hline 1999 & USA & Gardens and pools & Mayer et al. \\
\hline 1999 & USA & Housing characteristics & Plint \\
\hline 1999 & UK & Gardens and pools & Swyngedouw \\
\hline 2000 & USA & $\begin{array}{l}\text { Domestic household uses } \\
\text { Gardens and pools }\end{array}$ & Emrath \\
\hline 2000 & France & Housing characteristics & Nauges and Thomas \\
\hline 2003 & Spain & Gardens and pools & Domene and Saurí \\
\hline 2003 & Australia & Gardens and pools & Loh and Coghlan \\
\hline 2004 & Spain & Urban model & Domene et al. \\
\hline 2004 & Australia & Gardens and pools & Syme et al. \\
\hline 2004 & Australia & Housing characteristics & Troy and Holloway \\
\hline 2005 & Spain & Gardens and pools & Domene et al. \\
\hline 2005 & Australia & Gardens and pools & Troy et al. \\
\hline 2006 & Spain & Urban model & Domene and Saurí \\
\hline 2006 & Australia & Urban model & Hurd \\
\hline 2006 & USA & Urban model & Larsen and Harlan \\
\hline 2007 & Spain & Urban model & Rico \\
\hline 2007 & USA & Gardens and pools & Wentz and Gober \\
\hline 2008 & USA & Gardens and pools & Chestnutt et al. \\
\hline 2008 & Australia & $\begin{array}{l}\text { Urban model } \\
\text { Environmental perception of the residents }\end{array}$ & Randolph and Troy \\
\hline 2009 & USA & Urban model & Harlan et al. \\
\hline 2009 & USA & Gardens and pools & Larson et al. \\
\hline
\end{tabular}

Source: Authors 
Table 2 Studies about water consumption, household characteristics and urban model (continued)

\begin{tabular}{|c|c|c|c|}
\hline Year & Country & Variables & Authors \\
\hline 2011 & Spain & Gardens and pools & Fernández et al. \\
\hline 2011 & Spain & Gardens and pools & Hof and Schmitt \\
\hline 2011 & Italy & Urban model & Salvati and Sabbi \\
\hline 2011 & Spain & Gardens and pools & Vidal et al. \\
\hline 2012 & USA & Domestic household uses & Deoreo and Mayer \\
\hline 2013 & Spain & Urban model & García Acosta \\
\hline 2013 & Spain & Urban model & García et al. \\
\hline 2013 & Spain & Gardens and pools & Wolf and Hof \\
\hline 2014 & Spain & Domestic household uses & Albiol and Agulló \\
\hline 2014 & Spain & Gardens and pools & García Acosta \\
\hline 2014 & Spain & $\begin{array}{c}\text { Urban model } \\
\text { Gardens and pools }\end{array}$ & Hernández et al. \\
\hline 2015 & Spain & $\begin{array}{c}\text { Urban model } \\
\text { Gardens and pools }\end{array}$ & Gil et al. \\
\hline 2015 & Italy & Gardens and pools & Salvati et al. \\
\hline 2016a & Spain & Urban model & Morote and Hernández \\
\hline $2016 c$ & Spain & $\begin{array}{c}\text { Urban model } \\
\text { Gardens and pools }\end{array}$ & Morote and Hernández \\
\hline $2016 b$ & Spain & $\begin{array}{c}\text { Urban model } \\
\text { Gardens and pools }\end{array}$ & Morote and Hernández \\
\hline $2016 a$ & Spain & $\begin{array}{c}\text { Urban model } \\
\text { Gardens and pools }\end{array}$ & Morote et al. \\
\hline 2016b & Spain & $\begin{array}{c}\text { Urban model } \\
\text { Gardens and pools }\end{array}$ & Morote et al. \\
\hline
\end{tabular}

Source: Authors

Studies on the age of housing include those conducted by Nieswiadomy and Molina (1989) in the USA and Nauges and Thomas (2000) in France. Their results showed that the older the housing, the higher the consumption of water, due to the increased obsolescence of plumbing systems and a higher incidence of leaks. Studies focusing on the number of rooms (Barkatullah, 1996; Dandy et al., 1997) in Australia and the number of bathrooms (Chicoine and Ramamurthy, 1986; Barkatullah, 1996) in the USA and Australia, respectively, indicate that water consumption increases the older the property and the higher the number of rooms and bathrooms. Similar results were obtained in a study conducted in Madrid, Spain (Cubillo et al., 2008).

Several studies have examined the water consumption generated by recent trends in internal uses. Emrath (2000) and Deoreo and Mayer (2012) analysed water consumption for internal uses in single-family homes in the USA They found that domestic consumption had declined since 1995, and they predicted that this trend would continue as new water saving technologies were installed in increasingly more homes. They also highlighted the effect of the economic crisis, which has contributed to this drop in consumption since 2007. 
The association between water consumption and the urban model, i.e., the impact of a given urban typology on water consumption, has attracted increasingly more attention since mid-2005. Studies carried out by Troy et al., (2005) and Randolph and Troy (2008), both conducted in Australia could be cited. The latter was carried out in Sydney and it examined trends in domestic water consumption. The authors analysed the data provided by owner occupants concerning the following aspects: urban typology, the owner's socio-cultural profile and the owner's behaviour in terms of water use and the measures taken to reduce water consumption. In Spain, similar studies have been carried out in the Metropolitan Area of Barcelona (Domene and Saurí, 2006), Girona (García, 2013; García et al., 2013) and in the province of Alicante (Rico, 2007; Gil et al., 2015; Morote et al., 2016b).

A fourth approach was to examine the influence of external elements of the house (gardens and swimming pools) on water consumption. Research on swimming pools includes studies by Mayer et al. (1999) and Went and Gober (2007) in the USA, Syme et al., (1990-1991) in Australia and Salvati et al. (2015) in Italy. In Spain, studies focus on the Mediterranean coast: Wolf and Hof (2013) in the Balearic Islands, Vidal et al. (2011) in the Metropolitan Area of Barcelona and Morote et al. (2016a) in Alicante. The remarkable residential expansion recorded since the mid-nineties and the increase in the urban sprawl explains why it has got so much attention from the scientific community. Wentz and Gober (2007), for example, studied factors influencing domestic water consumption in housing developments in Arizona (USA), paying special attention to outdoor uses (mainly swimming pools). In the case of Alicante (Spain), Morote et al. (2016a) counted a total of 22,407 pools in only nine towns and they estimated an average water consumption of $105 \mathrm{~m}^{3} /$ year per pool and a percentage in some villages of $20 \%$ of the total local water consumption for these amenities.

However, the impact of gardens on domestic water consumption has got more research attention, largely due to the high volume of water consumed by these outdoor areas associated with the boom of suburban style housing and large lawns and yards in the post war period. A good example of this research is an Australian study by Hurd (2006) who analysed the role of the 'Atlantic gardens' (with a high presence of lawns) in increased water consumption. The research concluded that more than $50 \%$ of the total water consumed in a home was used to water the garden and that the typology of the garden was influenced by the price of water and the occupants' educational level. Emrath (2000) estimated the average consumption per house and day in various US and Canadian cities for the year 2000. The result was 1.548 l/house/day, of which 874.5 litres were for uses outside the home (56.45\%). In Spain, several studies have been conducted in the Mediterranean region (Domene and Saurí, 2003; Domene et al., 2005; Fernández et al., 2011; García Acosta, 2014; Hof and Schmitt, 2011; Morote and Hernández, 2014).

Further research on the interrelationship between water consumption and gardens includes studies on the impact of vegetation on water consumption (Larsen and Harlan, 2006; Larson et al., 2009), focusing especially on grass (Renwick and Archibald, 1998; Swyngedouw, 1999; Morote and Hernández, 2016b) as the dominant feature in many types of gardens, not only in Atlantic-type gardens. Another sub-theme concerns supply sources (Loh and Coghlan, 2003) and irrigation systems (Syme et al., 2004; Chestnutt et al., 2008). The first studied the use of irrigation systems (leak detection and repair programmes, recycling water, etc.), it analyses their costs and benefits as well as the improvements over time. 
Numerous studies have also related external water consumption to socio-demographic factors and more specifically age and area of origin. With regard to age, some studies have shown that more water is consumed in pensioner-occupied homes with gardens, due to the higher frequency of watering (Lyman, 1992). This was attributed to the deeply rooted love of gardening in the English-speaking world (which is expanded upon and imitated in the rest of the world) and an increase in free time spent on this activity after retirement (Padullés et al., 2016). This element shows the interrelationships between various factors and sometimes the contradictions. According to socio-demographic factors at an older age, water consumption is lower. However, this argument does not apply when a second factor is included as it is in the urban model.

In terms of the area of origin, a study conducted in the city of Phoenix (Arizona, USA), Wentz and Gober (2007) found that immigrants settling in a territory generally create the type of garden that is common in their home countries. They attributed this to acquired knowledge and the pleasure associated with a traditional garden model: evidently, this affects the water consumption generated by the garden. For instance, when immigrants from countries with mild humid climates, where Atlantic-type gardens predominate (deciduous plants and large lawns), settle in hotter areas, the consumption of water for irrigation increases because such plants require more water than the native vegetation. In the case of Spain, for example, Morote and Hernández (2014; 2016b) found that the immigrant population from northern and central Europe ('climate immigrant) who had settled along the coast of Alicante initially adopted landscaping patterns that are typical of an Atlantic climate, with large lawns, but subsequently modified these to reduce water consumption generated by the garden. The results obtained from interviews indicated that when these climate migrants acquired a house, they would create an Atlantic-type of garden where lawns were the dominant feature. However, over the years, an increase in water prices together with the costs associated with garden maintenance and water scarcity prompted them to transform their Atlantic gardens into Mediterranean-style gardens.

\subsection{Water consumption and political-economic factors}

The third subject matter identified concerns about the relationship between water consumption and the political-economic factors. In this area, studies have focused on factors such as the level of household income, water prices and policies adopted to regulate water consumption. There is a long history of these studies in the English-speaking world (from the 1980s) and especially in the USA, where several studies on the states of Arizona and Colorado have been carried out. Later (from the mid-1990s), the attention of research turned to Mediterranean areas as a result of the pressure arising from the demand for water due to the population growth and urban and residential dynamics.

With regards to the level of household income, many studies have reported that water consumption increases as income rises (Harlan et al., 2009); this relationship is attributed to the existence of various elements that favour consumption and also convey their owners' purchasing power. These include external elements of the house with high water demands, such as gardens and swimming pools, and some studies have in turn associated gardens with an increased property value (Syme et al., 1980) and the social status of their owners. The relationship between purchasing power and the urban model is obvious. For 
example, Morote et al. (2016a) explain that in Alicante (Spain) the presence of a pool in the house is one element that shows the 'economic power' of people who live in it.

Table 3 Studies about water consumption and political-economic factors

\begin{tabular}{|c|c|c|c|}
\hline Year & Country & Variables & Authors \\
\hline 1987 & USA & Level of household income & Hines et al. \\
\hline 1993 & USA & Level of household income & Berk et al. \\
\hline 1998 & Australia & Level of household income & Renwick and Archibald \\
\hline 1999 & USA & Level of household income & De Oliver \\
\hline 2003 & Europe & Water policies & Dalhuisen et al. \\
\hline 2009 & Europe & Water policies & Dalhuisen et al. \\
\hline 2004 & Spain & Level of household income & Domene et al. \\
\hline 2008 & USA & Water policies & Worthington and Hoffman \\
\hline 2009 & Europe & Water policies & Dalhuisen et al. \\
\hline 2010 & France & Level of household income & Millock and Nauges \\
\hline 2012 & Spain & Water policies & Sánchez García and Blanco Jiménez \\
\hline 2014 & Spain & $\begin{array}{l}\text { Level of household income } \\
\text { Water prices }\end{array}$ & Albiol and Agulló \\
\hline 2015 & Spain & $\begin{array}{l}\text { Level of household income } \\
\text { Water prices }\end{array}$ & Gil et al. \\
\hline 2016 & Spain & $\begin{array}{c}\text { Level of household income } \\
\text { Water prices }\end{array}$ & March and Saurí \\
\hline
\end{tabular}

Source: Authors

In Portland (Oregon, USA) Chang et al. (2010) highlight the fact that there is a threshold income to identify the relationship between income and water consumption. They assessed the role of urban development patterns on water demand using GIS and statistical models to analyse single-family residential water consumption. They found that the residential water consumption per household in the census block group scale is best explained by the average size of the building, followed by building density and the age of the building, with low water consumption areas clustering together and typically located in high-density and older neighbourhoods. Accounting for spatial dependence among residuals explanatory variables clarify up to $87 \%$ of the variations in water consumption.

Furthermore, increased domestic water consumption has been associated with a higher number of domestic appliances (washing machines, dishwashers, etc.); i.e., the higher the purchasing power, the higher the number of these items at home. However, this latter thesis has been corroborated to some extent in more recent studies, where it has been argued that domestic appliances have improved considerably in terms of water use efficiency over the last decade or more. In their studies of the Spanish Mediterranean coast, Gil et al. (2015) concluded that the use of new and more efficient appliances is one of the factors responsible for the recent drop in domestic water consumption, as new technologies can produce up to $40-60 \%$ savings compared to earlier versions. However, market penetration is linked to the homeowners' level of income, whereby a higher purchasing power implies a greater likelihood of using these technologies. 
In contrast to the aforementioned, other authors have claimed that higher income households consume less water as a result of greater environmental awareness (Morote et al., 2016b; March and Saurí, 2016) and, more recently, there are more water-efficient appliances, which is an argument that has already been discussed in the previous paragraph. The presence of these items and how they are associated with the drop in consumption has been analysed in studies such as those conducted by Hines et al. (1987) and Berk et al. (1993) in Los Angeles and the Bay of San Francisco (California), respectively. In France, Millock and Nauges (2010) concluded that environmental attitudes and the condition of the property in question were also factors that influenced the purchase of water-efficient appliances. They found that higher income households were more likely to invest in such devices than their lower income counterparts. However, in a study carried out in San Antonio (USA), De Oliver (1999) obtained results on water efficiency that contradicted those of the aforesaid studies; it was found that higher income population groups consumed more water. Inman and Jeffrey (2006) and Hurlimann et al. (2009) synthesised the social science perspective, focusing on the impact of personal characteristics and behaviour on the effectiveness of demand-related water management and conservation tools in the developed world.

A homeowner's purchasing power is an indicator that requires more research as it provides a better insight into the social differentiation of space. Thus, in their study on the Spanish Mediterranean coast, Gil et al. (2015) suggested that one of the possible causes for the drop in domestic water consumption was a decline in income levels, especially among the middle classes, as a result of the economic crisis that erupted in 2007. In turn, this crisis has prompted the adoption of strategies or measures to cut back on consumption or even, in some cases, to fraudulently reduce or evade water bills.

The price of water has also been addressed in numerous studies (Morote et al., 2016b). Renwick and Archibald (1998) conducted a study in California and explain that an increase in water prices resulted in a drop in water consumption, especially among lower income households. Since consumption was associated with the homeowner's level of income, it was also related to factors such as the type and the construction quality of housing, the elements within the home that consumed water and the existence of external uses (swimming pools and gardens). Arbués et al. (2003) examined the combination of time series and cross-section data to form panel data sets and specified functional form by estimating price and income elasticity for domestic water demand. They concluded that the price of water, income and household composition are crucial determinants of residential consumption. However, water demand is inelastic in terms of price (a change in price does not affect water demand significantly).

Through a meta-regression analysis of the variation in price and income elasticity of residential water demand, Dalhuisen et al. (2003) highlighted the fact that the variation in estimated elasticity is most significantly associated with differences in the underlying tariff system. In an updated review, Worthington and Hoffman (2008) addressed the empirical problems that arise in the selection and specification of the econometric water demand models. The authors, who compared the price and income elasticity findings on the basis of tariff metering, price structure and billing, warned that a continuing fundamental limitation of the water demand modelling is due to the lack of data concerning households and their demands for water. Also Gil et al., (2015) identified the increasing price of water associated with the economic crisis as being one of the factors that explained the reduction in water consumption in the city of Alicante (Spain). 
Lastly, some studies have focused on the economic policy instruments adopted to encourage sustainable water use. Dalhuisen et al. (2009) conducted a study on several European cities to analyse the water market for end users, focusing on the relevant characteristics of demand and supply, including market failures that warranted government intervention to regulate the market based on sustainability criteria. They analysed the potential of price instruments as well as the privatisation and liberalisation of the sector to encourage sustainable water consumption in urban areas. Their study was structured around a theoretical discussion of the principles of an optimal tariff system, consumer capacity to adapt to price changes, recouping social costs and the possibilities and desirability of changes in structural governance. In the case of Spain, Sánchez García and Blanco Jiménez (2012) have argued that water tariffs and prices are both used as tools to control consumption.

\subsection{Water consumption and psychological factors}

With regard to the psychological factors involved in water demand, studies in the USA (Arizona, New Mexico and Oregon) and Australia (cities of Sydney, Melbourne and Perth) predominated once again, in this case because of a long tradition in this line of research. Several aspects of this factor were considered, including studies that tried to associate water consumption with environmental psychology (environmental perception and awareness), social position and place attachment. Only very recently (from 2010) has research been regularly carried out on these factors by European researchers.

Among the noteworthy research work associating water consumption with the environmental perception is a study conducted by Jorgensen et al. (2009). These authors analysed the various factors that influence residents' perceptions, whereby particular attention is paid to the impact of neighbours' behaviour on their own water consumption. They argued that water consumption may increase when neighbours use water irresponsibly because the perception that others do not save water decreases motivation to adopt good water management practices. In turn, Aitken et al. (1991) studied the city of Melbourne (Australia) and found that household residents tended to consume the same volume of water as their neighbours. In another study of Australia, Askew and Mc Guirk (2004) tried to determine whether changes in individual attitudes or behaviours were the result of implementing practices in order to adapt to prevailing social norms in a particular area. Such changes can increase domestic water consumption, as they can affect the frequency and patterns of resource use, especially in gardens (García Acosta, 2012).

One of the main areas of research regarding environmental awareness concerns the various measures taken to save water. Flack and Greenberg (1987) organised interviews in seven communities in the northeast part of the state of Colorado (USA) to determine whether there was an association between environmental awareness and socioeconomic variables. Pro-environmental initiatives included water restrictions, limitations on the size of garden lawns and the installation of water saving elements and devices (Maddaus, 2001; Gaudin, 2006). In a study of the city of Sydney (Australia), Randolph and Troy (2008) found that water demand reduction strategies had been quite successful, but that domestic consumption remained high. These authors also analysed householders' attitudes to water consumption and observed that besides the psychological factors, water demand was also strongly linked to the type of housing and cultural and institutional aspects (March et al., 2015). 
Urban water consumption in water-stressed areas of the developed world

Table 4 Studies about water consumption and psychological factors

\begin{tabular}{|c|c|c|c|}
\hline Year & Country & Variables & Authors \\
\hline 1983 & USA & Social status of the residents & Geller et al. \\
\hline 1983 & USA & Place attachment of the residents & Proshansky et al. \\
\hline 1987 & USA & Environmental perception of the residents & Flack and Greenberg \\
\hline 1991 & Australia & Environmental perception of the residents & Aitken et al. \\
\hline 2001 & USA & Environmental perception of the residents & Maddaus \\
\hline 2004 & Australia & Environmental perception of the residents & Askew and Mc Guirk \\
\hline 2004 & Australia & Social status of the residents & Syme et al. \\
\hline 2006 & USA & Environmental perception of the residents & Gaudin \\
\hline 1999 & Italy & Place attachment of the residents & Bonaiuto et al. \\
\hline 2008 & Australia & Environmental perception of the residents & Randolph and Troy \\
\hline 2009 & Australia & Environmental perception of the residents & Jorgensen et al. \\
\hline 2012 & Spain & Social status of the residents & García Acosta \\
\hline 2013 & Spain & Social status of the residents & García et al. \\
\hline 2014 & Spain & Environmental perception of the residents & March et al. \\
\hline 2014 & Spain & Place attachment of the residents & Morote and Hernández \\
\hline 2015 & Spain & Environmental perception of the residents & March et al. \\
\hline 2016 & USA & Environmental perception of the residents & Straus et al. \\
\hline 2016 & Spain & Environmental perception of the residents & March and Saurí \\
\hline
\end{tabular}

Source: Authors

In Portland (Oregon, USA), Straus et al. (2016) examined the underlying attitudinal and behavioural factors of summer water consumption by combining survey responses from households and the corresponding empirical water consumption data. They found that pro-conservation attitudes regarding water usage (even when monitoring property size and other demographic variables) were valuable predictors of the actual drop in summer water consumption. Furthermore, these self-reported attitudes appear to have a direct impact on specific water consumption behaviours identified in the survey, with a potentially significant impact in two of three key areas of water conservation strategies: landscaping, adapting conservation technology, but not habitual use.

The second sub-theme identified concerns the social status of residents, and more specifically, residents with a higher socioeconomic status. This factor determined the adoption of behaviours and practices that led to increased water consumption due to the existence of elements such as swimming pools, Jacuzzis and gardens with lush vegetation and number of domestic appliances. Syme et al. (2004) analysed water consumption for outdoor residential uses in the city of Perth (Australia). They concluded that a certain lifestyle can lead to an increase in water consumption, mainly for leisure and recreation elements located outside the house (gardens and swimming pools). As external elements, gardens are an easy way for owners to show off their social status, defined in terms of income level (García et al., 2013) to their neighbours. Furthermore, when it comes to socioeconomic status, other studies have argued that water can be saved by adopting practices and appliances that reduce consumption, associating the installation of these with their owners' purchasing power and with other homeowners copying this. However, 
in one study conducted in the USA, Geller et al. (1983) reported that unlike the majority of findings and unlike what might be expected, the installation of these appliances resulted in an increase in water consumption. They found that the users' perceptions of conserving water led them to consume water more frequently for longer, a phenomenon referred to as 'offsetting behaviour' (García, 2012).

\subsection{Water consumption and climatic factors}

The last thematic area identified concerns the relationship between water consumption and weather conditions, and more specifically, the possible impact of temperatures and rain (Cabral et al., 2016). The general hypothesis is that water consumption increases as temperatures rise, and decreases as rainfall increases; more recently however, water consumption has also been linked to climate change (March et al., 2014). Gober (2010) claimed that urban areas located in arid regions are among those that are the most vulnerable to future water shortages, because climate change threatens to reduce supply and increase demand (ESPON-Climate, 2015).

Table 5 Studies about water consumption and climatic factors (temperature and rain)

\begin{tabular}{lcc}
\hline Year & Country & Authors \\
\hline 1986 & USA & Maidment and Miaou \\
1992 & USA & Nieswiadomy \\
2002 & USA & Timmins \\
2003 & Australia & Loh and Coghlan \\
2010 & USA & Gober \\
2011 & USA & Darrel et al. \\
2013 & Spain & Saurí et al. \\
2014 & Spain & Albiol and Agulló \\
2014 & USA & Breyer and Chang \\
2014 & USA & Chang et al. \\
2015 & Spain & Gil et al. \\
2016 & Portugal & Cabral et al. \\
2016 & Australia & Hemati et al. \\
$2016 c$ & Spain & Morote and Hernández \\
2016 & USA & Straus et al. \\
2016 & USA & Parandvash and Chang \\
\hline
\end{tabular}

Source: Authors

In the case of Australia, Loh and Coghlan (2003) observed that consumption increases in the summer due to a higher frequency of showers, washing and water used for external elements of the house. Numerous studies have analysed the impact of rainfall on water consumption; it should be noted however that many of them have also considered the effect of temperature (Nieswiadomy, 1992; Timmins, 2002; Darrel et al., 2011; Chang et al., 2014). There is an important interrelationship between these two factors, especially in semiarid climates where water consumption increases due to external elements of the house (gardens and swimming pools) as a result of losses associated with 
evapotranspiration in gardens and the evaporation of the water surface in pools. Maidment and Miaou (1986) studied data on daily water use in several cities in the states of Florida and Texas (USA), and concluded that the association between water use and air temperature was similar in cities located in the centre of each state and between cities in Texas and Florida. They also reported that water consumption increased slightly when maximum temperatures ranged between 4 and $21^{\circ} \mathrm{C}$, but that between 29 and $32^{\circ} \mathrm{C}$ it increased three to five fold per degree of temperature.

Breyer and Chang (2014) analysed the evolving response of daily water use to weather fluctuations (1981-2009) for two Portland-area municipal water providers. They report that temperature sensitivity, the response of water use to a temperature increase, generally declined for both water providers. They argue that a confluence of historical factors, including the 1992 drought, an aggressive (though uneven) demand management, changes to the building code and the on-going densification of urban and suburban areas have reduced per-capita water use and minimised the connection between water use and temperature. Modifying/diminishing the seasonality of water use is a major but oftenoverlooked component of urban climate change adaptation.

In the same area, Parandvash and Chang (2016) investigated the impact of long-term climate variability and the change per capita on water demand in urban and suburban service areas that have different degrees of development density. They used historical daily weather and water production data, socioeconomic data such as the population and unemployment rate to estimate daily water demand per capita. Without climate adaptation, compared to the historical period 1983-2012, per capita water demand is expected to increase by $10.6 \%$ in the $2035-2064$ period in suburban areas, while the per capita demand is expected to increase by $4.8 \%$ under the same scenario in urban areas with climate adaptation. Their findings will affect future urban water resource management and land use planning in the context of climate variability and change. They concluded that water resource management and urban planning has to be integrated to prepare for climate adaptation in municipal water planning and management.

In the study on the city of Alicante (southeast of Spain), which has similar temperatures and rainfall conditions to the semiarid regions of Australia or the USA, Gil et al. (2015) used weather conditions as one of the variables to analyse water consumption trends. Only $11.40 \mathrm{~mm}$ of rainfall was recorded in autumn of 2013. The autumn was extremely dry but temperatures were lower than in 2012, this was associated with the predominance of areas of low pressure, without rain, heavy cloud cover and less sun. In short, although the autumn was very dry, with lower temperatures and less solar radiation than average values; this resulted in a drop in the consumption of water. They concluded that these conditions partially explain the decrease in the total local water supply between 2012 and 2013. This decrease was included in a negative trend along with other factors such as the economic crisis, the increase in water prices or the spread of more efficient water appliances.

In Melbourne (Australia), Hemati et al. (2016) evaluate the relative importance of the climatic and anthropogenic drivers of urban water demand (using wavelet-based approaches) and the relative contribution of various water saving strategies to demand a reduction in water use during the millennium drought. They concluded that the main dominant driver was urban water savings (69\%), followed by a 'non-revenue' water reduction (29\%) and potable substitution with alternative sources such as rain or recycled water (3\%). Per capita consumption highlighted both climatic and anthropogenic 
signatures, with rainfall and temperature accounting for approximately $55 \%$ of the variance. Anthropogenic controls were also strong (up to $45 \%$ of the variance explained). These controls were non-stationary and frequency-specific, there were conservation measures like outdoor water restrictions effecting seasonal water use and technological innovation/changing social norms that had an impact on lower frequency (baseline) use.

\section{Discussions and conclusions}

The developed world has been witness to significant land changes since the second half of the twentieth century. In general, these have affected urban conglomerations, which are also often characterised by a shortage of water resources. Examples of this include the USA (e.g., Arizona, Texas, California or Oregon), the semiarid regions of Australia and the European Mediterranean. These areas have experienced high urban growth and an increasing density of the urban population. Both processes have been associated with a rising demand for resources, including water. Consequently, water resources have become an extremely popular research topic in studies carried out since the 1980s from a variety of perspectives, including geography, sociology, economics and environmental studies.

These studies have found that domestic water consumption is primarily influenced by the urban model, and social-demographic, psychological and political-economic factors, as well as weather conditions. In some studies, these factors have been interrelated; for example, economic factors interact with social factors or with the urban model. Most of the studies identified focused on the English-speaking world, and especially on arid and semiarid regions of Australia or areas with a high water demand for domestic uses (USA). Not only are they areas with the largest number of studies, but this is also where they were carried out first (1980s). In these areas urban processes have been more intensive and extensive over the time, particularly with regards to the development of low density housing where gardens and swimming pools have become the main factors behind a higher water consumption. In this sense, the studies that are related to water consumption and the urban model are predominant at an early stage in Australia, USA and later on in Mediterranean Europe. These studies are focused on water consumption that is influenced by the type of housing. They analysed the percentage of total domestic water consumption that these outdoor areas represent. It is important to highlight the fact that these studies that are currently being carried out in Europe (since 2000s) are due to the low urban expansion in the last few years. In this respect, these outdoor elements are typical of this urban sprawl where gardens and pools stand for a high percentage of water consumption.

An analysis of the factors influencing water consumption has revealed that in recent decades distinct thematic areas have emerged, and above all, that various factors have to a greater or lesser degree influenced consumption trends. There is a clear predominance of studies that analyse the influence of household characteristics and the urban model (47/111) on the rest of the drivers (political-economic and social-demographic, physiological and climatic factors) (Figure 2). The results obtained in relation to the latest number of residents per household, age and origin of residents are of particular interest, where different studies have presented conflicting findings. These themes have been discussed since the beginning of the 1980s while household characteristics have been discussed mainly from the 1990s. These studies have mainly been carried out in the USA 
and in secondly, in Australia. Some authors have argued that young people consume more water, while others have found that the water consumption level is higher among the retired population, especially if they have houses with gardens. Similar discrepancies are observed with economic variables (income level and the price of water), where authors report conflicting results and arguments. In general, these variables are analysed in the USA. Some studies have found that water consumption is lower in higher income households, and this has been attributed to the occupants having higher environmental awareness and there being a greater presence of water-efficient appliances. Others however have found that water consumption is higher in these households, due to of the existence of more water-consuming elements (gardens with lawns and lush vegetation), and because a higher income can lead to more water resources being wasted.

Figure 2 Number of studies according water consumption factors

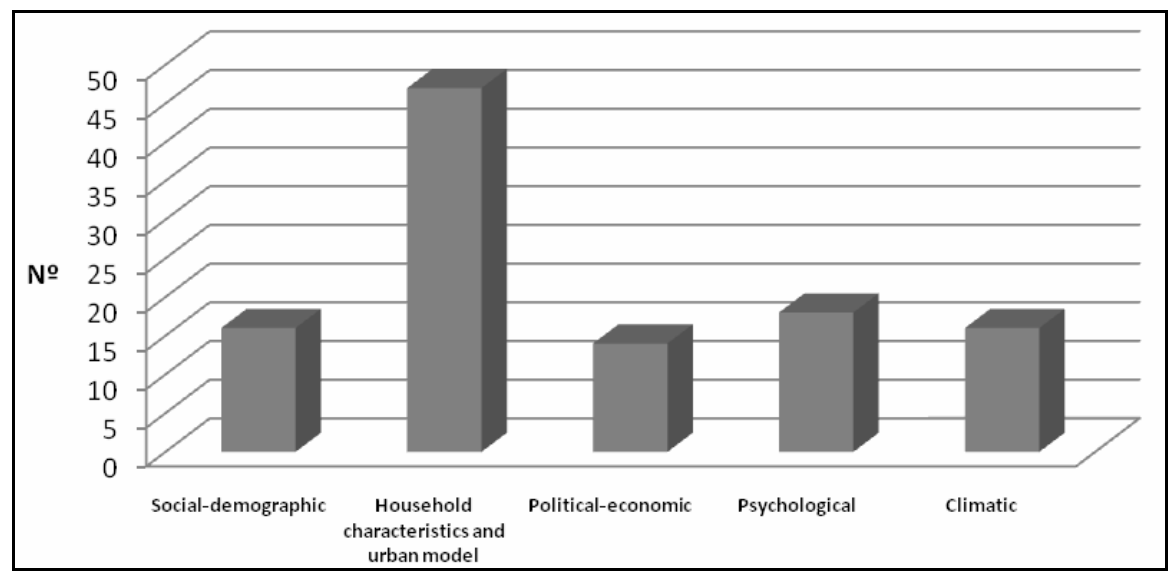

In the last few years studies have also been carried out in Europe that analyse the reasons why water consumption has decreased. Numerous studies associated with these results, have come up with possible reasons for this decrease that include:

a Technological innovation associated with installing new water-efficient appliances as well as water saving devices at home (taps, bathroom fittings, etc.), which have become popular since the late 1990s (Albiol and Agulló, 2014).

b Greater environmental awareness among the populace about saving water, thanks to more organised campaigns, especially in times of drought (March et al., 2015). Interesting results have been obtained in the studies about the reduction of water consumption in outdoor areas. It is important to explain that in recent years, the owners show greater environmental awareness and this is shown, for example, in the typology of their gardens, where native species that adapt better to the local environment are planted and require less water. This was confirmed in a study by Morote and Hernández (2014), who reported a change among immigrant garden owners from central and northern Europe to Mediterranean-type gardens that adapted better to the climate of the southeast Spanish coast. 
c The current economic crisis has led to a drastic fall in incomes and increased unemployment. One of the strategies used in response to this significant downturn has been to cut back on all domestic consumption, including water (Gil et al., 2015) especially among the middle classes.

d Water rates and prices have increased at a time when family incomes have dwindled.

e The efficiency of the water company supply networks has improved.

f Drinking water has been replaced by non-conventional water sources (reclaimed water and rainwater) for water public and private gardens (in some residential areas) and street cleaning (Rico, 2007).

g An ageing population. Albiol and Agulló (2014) observed that one of the reasons behind the drop in domestic water consumption along the Mediterranean coastline was the increase in the senior population and the loss of a younger population due to migration that was prompted by the economic crisis that erupted in 2007. They reported that a person aged 65 or more consumes $25 \%$ less water than the previous population segment (18 to 64 years).

Besides summarising research on the different factors influencing water consumption, the present literature review highlights the vital need to gain a better understanding of consumption patterns among the population and the factors that influence these practices in order to plan future water demand scenarios, especially in relation to drought events. This paper shows that more has been written on water consumption factors in areas where there is substantial urban growth. Besides, these areas are characterised by water scarcity. This is the reason why some authors focused their research work on studying the consequences of a growth in urban areas and to guarantee the supply of water for the population in developed countries. Thus, research in this area can contribute to the adoption of policies adapted to current social-economic and land realities, and as Chang et al. (2010) argue water resource planners and land-use planners should consider how to coordinate their respective efforts better to ensure the sustainability of urban water resources.

\section{References}

Aitken, C, Duncan, H and McMarthon, T.A. (1991) 'A cross-sectional regression-analysis of residential water demand in Melbourne, Australia', Applied Geography, Vol. 11, No. 2, pp.157-165.

Albiol, C and Agulló, F. (2014) 'La reducción del consumo de agua en España: causas y tendencias', Aquaepapers, Aquae Fundación.

Arbués, F., Garcia-Valinas, M.A., and Martinez-Espiñeira, E. (2003) 'Estimation of residential water demand: a state-of-the-art review', J. Socio Econ., Vol. 32, No. 1, pp.81-102, DOI: 10.1016/S1053-5357(03)00005-2.

Askew, L.E. and Mc Guirk, P.M. (2004) 'Watering the suburbs: distinction, conformity and the suburban garden’, Australian Geographer, Vol. 35, No. 1, pp.17-37.

Barkatullah, N. (1996) OLS and Instrumental Variable Price Elasticity Estimates for Water in Mixed-Effects Model Under Multiple Tariff Structure, Report 226, Department of Economics, University of Sydney, Sydney.

Berk, R.A., Schulman, D., Mc Keever, M. and Freeman, H.E. (1993) 'Measuring the impact of water conservation campaigns in California', Climatic Change, Vol. 24, No. 3, pp.233-248. 
Bonaiuto, M., Aiello, A., Perugini, M., Bonnes, M. and Ercolani, A.P. (1999) 'Multidimensional perception of residential environmental quality and neighbourhood attachment in the urban environment', Journal of Environmental Psychology, Vol. 19, No. 33, pp.331-352.

Breyer, B. and Chang, H. (2014) 'Urban water consumption and weather variation in the Portland, Oregon metropolitan area', Urban Climate, Vol. 9, pp.1-18.

Burriel, E. (2009) 'Los límites del planeamiento urbanístico municipal. El ejemplo valenciano', Documents d'Anàlisi Geogràfica, Vol. 54, pp.33-54.

Cabral, M., Mamade, A., Loureiro, D., Amado, C. and Covas, D. (2016) 'Modeling the effect of weather conditions on urban water demand in multiple network areas: a practical approach to improve monthly and seasonal operation', Journal of Water Supply: Research and Technology-Aqua, Vol. 65, No. 8, pp.612-625.

Chang, H., Parandvash, H. and Shandas, V. (2010) 'Spatial variations of single family residential water consumption in Portland, Oregon', Urban Geography, Vol. 31, No. 7, pp.953-972.

Chang, H., Praskievicz, S. and Parandvash, H. (2014) 'Sensitivity of urban water consumption to weather and climate variability at multiple temporal scales: the case of Portland', International Journal of Geospatial and Environmental Research, Vol. 1, Article 7.

Chen, Z., Ngo, H.H., Guo, W. and Eslamian, S. (2015) 'Water shortages', in Eslamian, S. (Ed.): Urban Water Reuse Handbook, pp.3-14, ch. 1, Taylor and Francis, CRC Group, USA.

Chestnutt, T., Fiske, G., Rothstein, E., Pekelney, D. and Beecher, J. (2008) 'Water efficiency programs for integrated water management', Journal/American Water Works Association, Vol. 100, No. 5, pp.132-141.

Chicoine, D. and Ramamurthy, G. (1986) 'Evidence on the specification of price in the study of domestic water demand', Land Economics, Vol. 62, No. 1, pp.26-32.

Cubillo, F., Moreno, T. and Ortega, S. (2008) 'Microcomponentes y factores explicativos del consumo doméstico de agua en la Comunidad de Madrid', Colección de Cuadernos de $I+D+I$, Canal de Isabel II.

Dalhuisen, J.M., Florax, R.J.G.M., De Groot, H.L.F. and Nijkamp, P. (2003) 'Price and income elasticities of residential water demand: a meta - analysis’, Land Econ., Vol. 79, No. 2, pp.292-308, DOI: 10.2307/3146872.

Dalhuisen, J., Nijkamp, P. and De Groot, H. (2009) 'Economic market instruments and sustainable urban water use, International Journal of Environmental Technology and Management', Vol. 11, Nos. 1-3, pp.88-101.

Dandy, G., Nguyen, T. and Davies, C. (1997) 'Estimating residential water demand in the presence of free allowances’, Land Economics, Vol. 73, No. 1, pp.125-139.

Darrel, G., Harlan, S.L., Stefanov, W.L. and Martin, C.A. (2011) 'Ecosystem services and urban heat riskscape moderation: water, green spaces and social inequality in Phoenix, USA', Ecological Applications, Vol. 21, No. 7, pp.2.637-2.651.

De Oliver, M (1999) 'Attitudes and inaction: a case study of the manifest demographics or urban water conservation', Environmental and Behavior, Vol. 31, No. 3, pp.372-394.

Deoreo, W.B. and Mayer, P.W. (2012) 'Insights into declining single-family residential water demands', Journal-American Water World Association, Vol. 104, No. 6, pp.383-394.

Domene, E. and Saurí, D. (2003) 'Modelos urbanos y consumo de agua, El riego de jardines privados en la Región Metropolitana de Barcelona', Investigaciones Geográficas, Vol. 32, No. 32, pp.5-17.

Domene, E. and Saurí, D. (2006) 'Urbanization and water consumption: influencing factors in the Metropolitan Region of Barcelona’, Urban Studies, Vol. 43, No. 9, pp.1.605-1.623.

Domene, E., Saurí, D. and Parés, M (2005) 'Urbanization and sustainable resource use: the case of garden watering in the metropolitan region of Barcelona', Urban Geography, Vol. 268, No. 6, pp.520-535. 
Domene, E., Saurí, D., Molina, J. et al. (2004) Estudi del consum d'aigua als edificis de la Regió Metropolitana de Barcelona: Situació actual y possibilitats d'estalvi [online] http://www.fundacioabertis.org/rcs_est/estudi_complet.pdf (accessed 07 November 2015).

Emrath, P. (2000) 'Residential water use', Housing Economics, Vol. 48, No. 48, pp.6-10.

ESPON-Climate (2015) Climate Change and Territorial Effects on Regions and Local Economies in Europe [online] http://www.espon.eu/main/Menu_Projects/Menu_AppliedResearch/ climate.html (accessed 13 November 2016).

Fernández, R., Ordovás, J. and Herrera, M.A. (2011) 'Domestic gardens as water-wise Landscapes: a case study in Southwestern Europe', HorTechnology, Vol. 21, No. 5, pp.616-623.

Fernández, S. and Barrado, D.A. (2011) 'El desarrollo turístico-inmobiliario de la España mediterránea e insular frente a sus referentes internacionales (Florida y la Costa Azul): un análisis comparado’, Cuadernos de Turismo, No. 27, pp.373-402.

Flack, J.E. and Greenberg, J. (1987) 'Public attitudes toward water conservation', Journal of the American Water Works Association, Vol. 79, No. 3, pp.46-51.

Fundación Aquae (2015) [online] http://www.fundacionaquae.org/wiki/ahorrar-agua-en-el-inodoro (accessed 22 March 2016).

García Acosta, X. (2012) Nous procesos d'urbanització i consum d'aigua per a usos domestics: Una exploració de relacions a l'àmbit gironí, PhD Thesis. University of Girona, Spain.

García Acosta, X. (2013) 'Urbanització difusa i consum d'aigua per a usos domèstics. Una exploració de relacions’, Documents d’Anàlisi Geogràfica, Vol. 59, No. 2, pp.347-362.

García Acosta, X. (2014) 'Jardines privados y consumo de agua en las periferias urbanas de la comarca de la Selva (Girona)’, Investigaciones Geográficas, No. 61, pp.55-69.

García, X., Llausas, A. and Ribbas, A (2013) 'Landscaping patterns and sociodemographic profiles in suburban areas: implications for water conservation along the Mediterranean coast', Urban Water Journal, Vols. 3/11, No. 1, pp.31-41.

Gardener, G.T. and Stern, P.C. (1996) Environmental Problems and Human Behavior, $1^{\mathrm{a}}$ ed., Allyn and Bacon, Boston.

Gaudin, S. (2006) 'Effect of price information on residential water demand', Applied Economics, Vol. 38, pp.383-393.

Gaudin, S., Griffin, R.C. and Sickles, R.C. (2001) 'Demand specification for municipal water management: evaluation of the Stone-Geary form', Land Economics, Vol. 77, No. 3, pp.399-422.

Geller, E.S., Erikson, J.B. and Buttram, B.A. (1983) 'Attempts to promote residential water conservation with educational, behavioral and engineering strategies', Population and Environment, Vol. 6, No. 2, pp.96-112.

Gil, A.O., Hernández Hernández, M., Morote Seguido, A.F., Rico Amorós, A.M., Saurí Pujol, D. and March Corbella, H. (2015) Tendencias del consumo de agua potable en la ciudad de Alicante y Área Metropolitana de Barcelona 2007-2013, Hidraqua, Gestión Integral de Aguas de Levante S.A. y la Universidad de Alicante.

Gober, P. (2010) 'Desert urbanization and the challenges of water sustainability', Curr.Opin. Environment Sustainability, Vol. 2, No. 3, pp.144-150.

Gregory, G.D. and Di Leo, M. (2003) 'Repeated behavior and environmental psychology: the role of personal involvement and habit formation in explaining water consumption', Journal of Applied Social Psychology, Vol. 33, No. 6, pp.1.261-1.296.

Griffing, R.C. and Chang, C. (1990) 'Pretest analysis of water demand in thirty communities', Water Resources Research, Vol. 26, No. 10, pp.2.251-2.255.

Harlan, S.L., Yabiku, S.T., Larsen, L. and Brazel, A.J. (2009) 'Household water consumption in an arid city: affluence, affordance and attitudes', Society and Natural Resources, Vol. 22, No. 8, pp.691-709. 
Hemati, A., Rippy, M.A., Grant, S.B., Davis, K. and Feldman, D. (2016) 'Deconstructing demand: the anthropogenic and climatic drivers of urban water consumption', Environmental Science and Technology.

Hernández, M., Morales, A. and Saurí, D. (2014) 'Ornamental plants and the production of nature(s) in the Spanish real estate boom and bust: the case of Alicante', Urban Geography, Vol. 35, No. 1, pp.71-89.

Hines, J.M., Hungerford, H.R. and Tomera, A.N. (1987) 'Analysis and synthesis of research on responsible environmental behavior: a meta-analysis', Journal of Environmental Education, Vol. 18, No. 2, pp.1-18.

Hof, A. and Schmitt, T (2011) 'Urban and tourist land use patterns and water consumption: evidence from Mallorca, Balearic Islands', Land Use Policy, Vol. 28, No. 4, pp.792-804.

House-Peters, L. and Chang, H. (2011) 'Urban water demand modelling: Review of concepts, methods, and organizing principles', Water Resources Research, Vol. 47, No. 5, DOI: $10.1029 /$ 2010WR009624.

Hurd, B.H. (2006) 'Water conservation and residential landscape: household preferences, household choices', Journal of Agricultural and Resource Economics, Vol. 31, No. 2, pp.21-32.

Hurlimann, A., Dolnicar, S. and Meyer, P. (2009) 'Understanding behaviour to inform water supply management in developed nations: a review of literature, conceptual model and research agenda', J. Environ. Manage., Vol. 91, No. 1, pp.47-56, DOI: 10.1016/ j.jenvman.2009.07.014.

Inman, D. and Jeffrey, P (2006) 'A review of residential water conservation tool performance and influences on implementation effectiveness', Urban Water J., Vol. 3, No. 3, pp.127-143.

Intergovernmental Panel on Climate Change (2014) Climate Change 2013 and Climate Change 2014, (3 vols.), [online] http://www.ipcc.ch (accessed 13 April 2015).

Jorgensen, B., Graymore, M. and O’toole, K. (2009) 'Household water use behavior: an integrated model', Journal of Environmental Management, Vol. 91, No. 1, pp.227-236.

Larsen, L. and Harlan, S.L. (2006) 'Desert dreamscapes: residential landscapes preference and behavior', Landscape and Urban Planning, Vol. 78, Nos. 1-2, pp.85-100.

Larson, K.L., Casagrande, D., Harlan, S.L. and Yabiku, S.T. (2009) 'Residents yard choices and rationales in a desert city: social priorities, ecological impacts, and decision tradeoffs', Environmental Management, Vol. 44, No. 5, pp.921-937.

Llausàs, A. and Saurí, D. (2016) 'A research synthesis and theoretical model of relationships between factors influencing outdoor domestic water consumption', Society and Natural Resources, Vol. 30, No. 2, pp.377-392, DOI: 10.1080/08941920.2016.1185559.

Loh, M. and Coghlan, P. (2003) Domestic water use study: Perth, Western Australia 1998-2001, Water Corporation, Perth.

Lyman, R.A. (1992) 'Peak and off-peak residential water demand', Water Resources Research, Vol. 28, No. 9, pp.2.159-2.167.

Maddaus, L.A. (2001) Effects of Metering on Residential Water Demand, University of California.

Maidment, D. and Miaou, S. (1986) 'Daily water use in nine cities', Water Resources Research, Vol. 22, No. 6, pp.845-851.

March, H. and Saurí, D. (2016) 'When sustainable may not mean just: a critical interpretation of urban water consumption decline in Barcelona', Local Environment, Vol. 22, No. 5, pp.1-13 [online] http://dx.doi.org/10.1080/13549839.2016.1233528 (accessed 28 September 2016).

March, H., Perarnu, J. and Saurí, D. (2012) 'Exploring the links between immigration, ageing and domestic water consumption: the case of the Metropolitan area of Barcelona', Regional Studies, Vol. 46, No. 2, pp.229-244. 
March, H., Saurí, D. and Olcina, J. (2014) 'Rising temperatures and dwindling water supplies? Perception of climate change among residents of the Spanish Mediterranean tourist coastal areas', Environmental Management, Vol. 53, No. 1, pp.181-193, DOI: 10.1007/s00267-0130177-7.

March, H., Hernández, M. and Saurí, D. (2015) 'Percepción de recursos convencionales y no convencionales en áreas sujetas a estrés hídrico: el caso de Alicante’, Revista de Geografía Norte Grande, No. 60, pp.153-172.

Mayer, P.W., Deoreo, W.B., Optiz, E., Kiefer, J., Dziegielewski, B. and Davis, W. (1999) Residential End Uses of Water, American Water Works Association Research Foundation, Denver.

Membrado, J.C. (2015) 'Migración residencial y urbanismo expansivo en el mediterráneo español', Cuadernos de Turismo, No. 35, pp.259-285.

Millock, K. and Nauges, C. (2010) 'Household adoption of water-efficient equipment: the role of socio-economic factors, environmental attitudes and policy', Environmental and Resource Economics, Vol. 46, No. 4, pp.539-565.

Mitchell, J. (2001) 'Urban sprawl', National Geographic, No. 200, pp.48-56.

Morote Seguido, A.F. and Hernández, M. (2014) 'Jardines y urbanizaciones, nuevas naturalezas urbanas en el litoral de la provincia de Alicante', Documents d'Anàlisi Geogràfica, Vol. 60, No. 3, pp.483-504.

Morote, A.F. and Hernández, M. (2016a) 'Urban sprawl and its effects on water demand: a case study of Alicante, Spain', Land Use Policy, Vol. 50, pp.352-362 [online] http://dx.doi.org/ 10.1016/j.landusepol.2015.06.032 (accessed 5 April 2016).

Morote, A.F. and Hernández, M. (2016b) 'Jardines y patrones de ajardinamiento en las urbanizaciones del litoral de Alicante’, Boletín de la Asociación de Geógrafos Españoles, No. 70, pp.31-56.

Morote, A.F. and Hernández, M. (2016c) 'Green areas and water management in residential developments in the European Western Mediterranean: a case study of Alicante, Spain', Danish Journal of Geography, Vol. 116, No. 2, pp.190-201 [online] http://dx.doi.org/10.1080/ 00167223.2016.1211483 (accessed 10 May 2016).

Morote, A.F., Saurí, D. and Hernández, M. (2016a) 'Residential tourism, swimming pools and water demand in the Western Mediterranean', Professional Geographer, Vol. 69, No. 1, pp.1-11, DOI: 10.1080/00330124.2015.1135403.

Morote, A.F., Hernández, M. and Rico, A.M. (2016b) 'Causes of domestic water consumption trends in the city of Alicante: exploring the links between the housing bubble, the types of housing and the socio-economic factors', Water, Vol. 8, No. 374, pp.1-18, DOI: 10.3390/ w8090374.

Nauges, C. and Reynaud, A. (2001) 'Estimation de la demande domestique d'eau potable en France’, Revue Économique, Vol. 52, No. 1, pp.167-185.

Nauges, C. and Thomas, A. (2000) 'Privately-operated water utilities, municipal price negotiation and estimation of residential water demand: the case of France', Land Economics, Vol. 76, No. 1, pp.68-85.

Nazari, R., Khanbilvardi, R., Hoyos, S. and Eslamian, S. (2013) 'Freshwater demands and storages, Encyclopedia of Crises Management, Sage Publication.

Nieswiadomy, M. (1992) 'Estimating urban residential water demand: effects or price structure, conservation and education’, Water Resources Research, Vol. 28, No. 3, pp.609-615.

Nieswiadomy, M. and Molina, D. (1989) 'Comparing residential water demand estimates under decreasing and increasing block rates using household data', Land Economics, Vol. 65, No. 3, pp.280-289.

Padullés, J., Vila, J. and Barriocanal, C. (2016) 'Floristic and structural differentiation between gardens of primary and secondary residences in the Costa Brava (Catalonia, Spain)', Urban Ecosystems, Vol. 19, No. 1, pp.505-521 [online] DOI: http://dx.doi.org/10.1007/s11252-0150496. 
Parandvash, H. and Chang, H. (2016) 'Analysis of long-term climate change on per capita water demand in urban versus suburban areas in the Portland metropolitan area, USA', Journal of Hydrology, Vol. 538, pp.574-586.

Plint, E.A. (1999) 'Household responses to increased water during the California drought', Land Economics, Vol. 71, No. 2, pp.92-173.

Proshansky, H.M., Fabian, A.K. and Kaminoff, R. (1983) 'Place identity: physical world socialization of the self', Journal of Environment Psychology, Vol. 3, No. 1, pp.57-83.

Randolph, B. and Troy, P. (2008) 'Attitudes to conservation and water consumption', Environmental Science and Policy, Vol. 11, No. 5, pp.441-455.

Renwick, M. and Archibald, S. (1998) 'Demand side management policies for residential water use: who bears the conservation burden?', Land Economics, Vol. 74, No. 3, pp.343-359.

Rico, A.M. (2007) 'Tipologías de consumo de agua en abastecimientos urbano-turísticos de la Comunidad Valenciana’, Investigaciones Geográficas, No. 42, pp.5-34.

Sánchez García, V.E. and Blanco Jiménez, F.J. (2012) 'El uso sostenible del agua en núcleos urbanos: las tarifas como herramienta de control del consumo', Observatorio Ambiental, Vol. 15, pp.35-59.

Salvati, L. and Sabbi, A. (2011) 'Exploring long term land cover changes in an urban region of Southern Europe', International Journal of Sustainable Development and World Ecology, Vol. 18, No. 4, pp.273-282.

Salvati, L., Ridolfi, E., Zambon, I., Serra, P. and Saurí, D. (2015) 'Swimming pools as indicator of urban sprawl: an exploratory analysis in a Mediterranean City’, International Journal of Environmental Research, Vol. 9, No. 4, pp.1325-1332.

Saurí, D. (2013) 'Water conservation: theory and evidence in urban areas of the developed world', Annual Review of Environment and Resources, Vol. 38, pp.227-248, DOI: 10.1146/ annurev-environ-013113-142651.

Saurí, D., Olcina, J., Vera, J.F., Martín-Vide, J., March, H., Serra-Llobet, A. and Padilla, E. (2013) 'Tourism, climate change and water resources: coastal mediterranean spain as an example', in Schmidt-Thome, P. and Greving, S. (Eds.): European Climate Vulnerability and Adaptation: A Spatial Planning Perspective, , pp.231-252, John Wiley \& Sons, Ltd.

Sotelo, J.A., Olcina, J., García, F. and Sotelo, M. (2012) 'Huella hídrica de España y su diversidad territorial’, Estudios Geográficos, Vol. LXXIII, No. 272, pp.239-272.

Straus, J., Chang, H. and Hong, C.Y. (2016) 'An exploratory path analysis of attitudes, behaviors and summer water consumption in the Portland Metropolitan area', Sustainable Cities and Society, Vol. 23, pp.68-77.

Swyngedouw, E. (1999) 'Modernity and hibridity: nature, regeneracionism, and the production of the Spanish waterscape, 1890-1930', Annals of the Association of American Geographers, Vol. 89, No. 3, pp.443-465.

Syme, G.J., Kantola, S.J. and Thomas, J.F. (1980) 'Water resources and the quarter acre block'. in Thorne, R. and Arden, S. (Eds.): People and the Man Made Environment, 1 ${ }^{\mathrm{a}}$ ed., pp.192-201, University of Sydney, Sydney.

Syme, G.J., Seligman, C. and Thomas, J.F. (1990-1991) 'Predicting water consumption from homeowner’s attitudes’, Journal of Environmental Systems, Vol. 20, No. 2, pp.157-168.

Syme, G.J., Shao, Q., Po, M. and Campbell, E. (2004) 'Predicting and understanding home garden water use', Landscape and Urban Planning, Vol. 68, No. 1, pp.121-128.

Timmins, C. (2002) 'Measuring the dynamic efficiency costs of regulators preferences: municipal water utilities in the arid West', Econometrica, Vol. 70, pp.603-629.

Troy, P. and Holloway, D. (2004) 'The use of residential water consumption as an urban planning tool: a pilot study in Adelaide', Journal of Environmental Planning and Management, Vol. 47, No. 1, pp.97-114. 
Troy, P., Holloway, D. and Randolph A.B. (2005) Water Use and the Built Environment: Patterns of Water Consumption in Sydney, City Futures Research, Report no.1, City Futures Research Centre, Faculty of Built Environment, UNSW, Kensigton.

Vera, J.F., Casado, J.M. and Ramón, A.B. (2004) 'Consideraciones sobre el impacto del Plan Hidrológico Nacional en el sector turístico de la provincia de Alicante. Repercusiones socioeconómicas del Plan Hidrológico Nacional en la provincia de Alicante', Fundación COEPA, pp.205-267.

Vidal, M., Domene, E. and Saurí, D. (2011) 'Changing geographies of water-related consumption: residential swimming pools in suburban Barcelona’, Area, Vol. 43, No. 1, pp.67-75.

Wentz, E. and Gober, P. (2007) 'Determinants of small-area water consumption for the city of Phoenix, Arizona', Water Resources Management, Vol. 21, No. 11, pp.1.849-1.863.

Wolf, N. and Hof, A. (2013) 'Integration of the pixel and object domain for the mapping of new urban landscapes in the Mediterranean with a focus on outdoor water consumption', EARSeL eProceedings, Vol. 12, No. 1, pp.67-81.

Worthington, A.C. and Hoffman, M. (2008) 'An empirical survey of residential water demand modeling', J. Econ. Surv., Vol. 22, No. 5, pp.842-871, DOI: 10.1111/ j.1467-6419.2008.00551.x. 